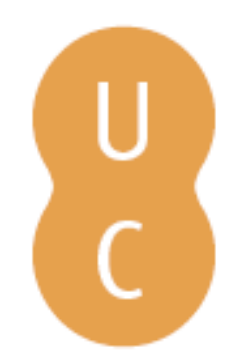

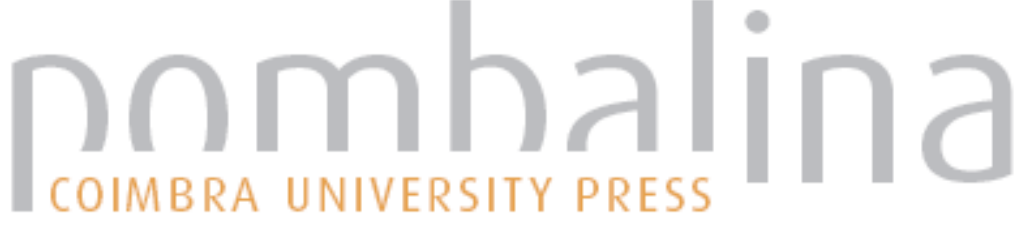

\section{Looking into coaching children from an instructional perspective}

\author{
Autor(es): $\quad$ Graça, Amândio
}

Publicado por: Imprensa da Universidade de Coimbra

URL

persistente: URI:http://hdl.handle.net/10316.2/32254

DOI: $\quad$ DOI:http://dx.doi.org/10.14195/978-989-26-0474-9_12

Accessed : $\quad$ 26-Apr-2023 14:22:36

A navegação consulta e descarregamento dos títulos inseridos nas Bibliotecas Digitais UC Digitalis, UC Pombalina e UC Impactum, pressupõem a aceitação plena e sem reservas dos Termos e Condições de Uso destas Bibliotecas Digitais, disponíveis em https://digitalis.uc.pt/pt-pt/termos.

Conforme exposto nos referidos Termos e Condições de Uso, o descarregamento de títulos de acesso restrito requer uma licença válida de autorização devendo o utilizador aceder ao(s) documento(s) a partir de um endereço de IP da instituição detentora da supramencionada licença.

Ao utilizador é apenas permitido o descarregamento para uso pessoal, pelo que o emprego do(s) título(s) descarregado(s) para outro fim, designadamente comercial, carece de autorização do respetivo autor ou editor da obra.

Na medida em que todas as obras da UC Digitalis se encontram protegidas pelo Código do Direito de Autor e Direitos Conexos e demais legislação aplicável, toda a cópia, parcial ou total, deste documento, nos casos em que é legalmente admitida, deverá conter ou fazer-se acompanhar por este aviso.

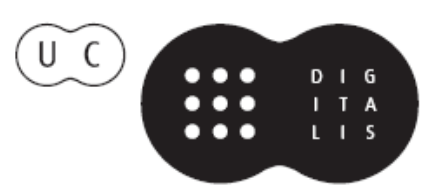


Carlos Eduardo Gonçalves

Sean P. Cumming

Manuel J. Coelho e Silva

Robert M. Malina

(Editors)

\section{Sport \\ and Education}

Oribute to OMaxtin Lee

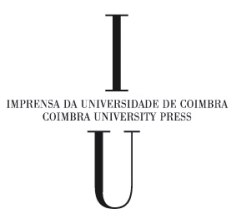




\author{
Amândio Graça \\ University of Porto, Portugal
}

\title{
LOOKING INTO COACHING CHILDREN FROM AN INSTRUCTIONAL PERSPECTIVE
}

\section{The mission first: purposes and values}

In a context-free definition, instructional capacity will be devoid of meaning. It cannot be defined in a vacuum; it has to be related to places and times, to particular social, institutional, and historical contexts. Therefore, the first task of any coach is to examine his/her situation, what society expects of him/her, what should be done in benefit of participants' life or what could be done to improve sport practice.

Answering those critical questions would enable the coaches to clarify their mission within the organization they work for, and help their organization to set down its unique mission in a so complex and multidimensional world of sport, pervaded by an array of individual purposes, meanings and aptitudes.

Aiming at excellence in sport and providing a positive sport experience are two crucial goals pursued by sport programs, but whereas the first one is more markedly elitist and selective, the second is more inclusive and approachable. As Kretchmar (1994) emphasizes, meaning and pleasure are rather more democratic values, because they are within the reach of all participants, and they have no request for a high level performance.

On the other hand, the very idea of sport practice, as much inclusive as it could be, can never be deprived of requirements of challenge, effort, commitment, improvement, and achievement.

It seems evident that between striving for excellence and providing a positive experience for all participants there is always a tension that tends to confound coaches and sport organizations in the statement of their missions. Contradictory discourses and practices are fruit of a sport culture whose sense of mission is neither understood nor assumed by those who are directly implicated in the sports practice for children and youth and also by those who have general public responsibility (Kirk, 2004).

It is not fair to speak about the educational values of youth sports for all children, and then to organize it only according to the rules of selectivity and exclusion. Sport for all children is completely misconceived when we take it as singular building guided by noble well intentioned principles, in theory, but governed by the "winners in, losers out" rule, in practice. As Kirk and Gorely (2004) explained, the elite sport 
model is not suited to frame the entire youth sport programs or physical education. Because of its pyramidal configuration elite sport inevitably produces exclusion. The authors presented an alternative model for lifelong involvement in sport, which is a truly inclusive model, displaying space either for those who wish and can pursuit excellence. This means that the pursuit of excellence has not to be unfair to sport children programs. However it must be a path track among other tracking alternatives. Excellence is a seminal goal of sport, as well as of any other human theoretical or practical domain. Excellence in sport, as in dance or music, is a long term pursuit and the preparation process has to begin early in the childhood years (Ericsson, 2003; Ericsson et al 1993). If it is true that excellence is restricted to a minority of gifted candidates, it is no less true that it does not discard years of strong willed dedication to a specific high demanding preparation.

Nevertheless, it is always necessary to affirm that excellence should never fail to respect any athlete as a person, and that being involved in a high demanding training program should not impede the attainment of a positive sport experience. As Martin Lee (1993) never gives up to advise us, put the child before sports; and children rank "pleasure" much more higher than "win".

All this to say that youth coaches should try to clarify their goals, their priorities, the guidelines that direct their intervention in order to be able to act coherently and succeed in their educational mission.

\section{Influence of social context on the instructional capacity of coaching programs}

The intent of sport training is to develop, consolidate and refine knowledge, skill and disposition that sustain the quality of participation and performance in sport. The training of quality will be the one that will exhibit better instructional capacity, i.e. better capacity to enhance athletes' learning and growth.

The instructional capacity is neither exclusively a consequence of personal and technical attributes of coaches, nor the result of particular characteristics or potentialities of athletes. It is also influenced by several factors of physical, social and cultural contexts, which appear either as opportunities, resources, sources of incentive and support, or as constraints, obstacles, sources of discouragement and criticism.

Material resources and available conditions for training and competition, namely the quality and number of spaces, facilities and training tools; the time available for training, are seen as beneficial or detrimental for the success of the training programs. It is noteworthy, however, that the resources per se do not make the difference, in so for that two coaches with exactly the same resources and having athletes with identical potential can implement very different training processes, and produce clearly distinct results, which can be endorsed to the ability to optimize the allocated time for training, and the available resources. At last, in matter of resources, being them material, human, financial, or of any other nature, it is not a mere question of availability, but rather a question of use; and the important thing is to make good use of them.

Also the organization of the club, its traditions and norms; the expectations of coaches and directors, their orientations towards the training process, their standards and mechanisms of performance appraisal, value ascribing and merit acknowledgement 
establish a social and cultural context that can either be encouraging or detrimental to the development of instructional capacity of coaches and sport education programs.

Another factor with a significant impact on the instructional capacity of sport training programs is the attitude of parents of young athletes towards their practice. Parents condition the participation of children in training sessions and competition. Many parents take interest and follow closely the sport practice of their children. A few parents volunteer to coach, or to help in some way the program of their children.

Parents hold goals and expectations for their children's practice, which may or may be not in accordance with coaches' orientation and evaluation. As a consequence, similarity of perspectives makes easier and reinforces collaboration, while divergence tends to set parents against coaches' work and defy decisions concerning their children.

There are parents who encourage their children, and parents who push excessively hard over their children or assume abusive, unacceptable behaviour during sport contexts; as there parents who purely ignore the practice of their children. All of these stances affect the development of the training process, in so far that they affect the activity of coaches and athletes, the quality of interpersonal relationship and coaching climate.

The instructional capacity of the coaching program will be enhanced with a sound partnership between coaches and parents, if there is a good co-ordination of goals, efforts and willingness between coaches and parents of young athletes.

\section{Instruction as interaction between coaches athletes and contents of coaching}

Definition of instruction is commonly restricted to the activity of teachers or coaches, or yet more specifically to the verbal activity related to information delivery. A completely different conception is that advanced by Cohen and Ball, which views instruction as an interactive process between teacher (coach), students (athletes), and content. In the instructional process (1) coaches figure out the needs, interests, and responses of athletes during training and competition; (2) coaches design, select, and modify the tasks of training programs; (3) coaches present tasks, give explanations, communicate expectations and criteria about what to do, and how to do in the practice and competition; (4) coaches supervise, direct, manage, and support athletes activity during training and competition.

If you go no further in the definition of instruction, you will put athletes in the position of mere object of the coaches' activity, even if you take care to configure instruction as an activity sensitive to the particularities of athletes and contents.

The instructional process is not uniquely confined to the coaches' action, but rather involves the joint action of coaches and athletes on a specified content in a given setting, during a certain period of time. Athletes are not passive elements in the development of coaching activities. Athletes bring with them knowledge, skills and dispositions, expectations and motivation that necessarily influence what could happen, and what actually take place in training and competition. Athletes attend to, interpret, and respond to coaches' interventions and demands, or to tasks requirements, in such a way that will act upon both the development of coaches' action and the content actually activated on training and competition. It is therefore clear that the coaching is a joint construction of coaches and athletes. 
Coaches who seek to improve the instructional capacity of their coaching programs do not concentrate all the responsibilities of instruction; they allow for and stimulate other sources of instruction, namely the athletes. They want that their athletes explore and find productive solutions; they make use of small group work and cooperative learning; they nurture a self accountability climate in which athletes may commit to the goals and tasks of training, share each other's experiences and knowledge, do not keep waiting for coaches to tell them what they must do. More advanced and more experienced athletes can model behaviours and skills, and can amplify the sources of feedback and scaffold the learning activity for their peers.

Coaches and athletes work on training contents chiefly trough movement tasks (i.e. exercises and exercise series), which mean that the success of training relies, in large measure, on the quality and efficacy of the movement tasks coaches introduce (Queiroz, 1986). Being able to select and organize appropriate movement tasks is therefore a critical aspect of the coaches' instructional capacity. From the past experience as an athlete; from seeing and hearing other coaches at work; from consulting books, reviews, or retrievals on electronic sources; from coach education programs, or by attending workshops and clinics coaches amass exercises or ideas to delineate exercises to design and refine their own coaching practice.

However, even the best conceived exercises for the instruction, the best aligned with the logic of the training program will attain the desired effect if coaches are knowledgeable and use that knowledge conveniently in order to coordinate instruction, support and correct athletes' execution; and, on the other hand, if athletes commit themselves to working towards the instructional goals.

\section{Improving the instructional capacity of youth coaching programs}

Even if barely acknowledged by coaches, athletes are one of the most important sources of learning for coaches. We dare say that are the athletes who make the coaches, as they proportionate them the experience they need, the material for reflecting and improving their practice. If coaches' explanations are confuse, verbose, inconsistent, contradictory, or flawed the way athletes respond will be also rather informative. If tasks are poorly designed, misconceived, unfocused, inadequate in terms of duration, intensity or difficulty level, athletes' ineffectual responses will become more and more evident along the time. If the coaches are not able to establish challenging requirements and a feasible accountability system, the way athletes will respond will rest far below the desired expectations.

At this point it could be wise to say that experience and even reflection on experience, being indispensable, do not generate necessarily desired learning outcomes. It is also possible that dull experience can reinforce a kind of managerial, unchallenging training. Worst yet, it is also possible to refine a kind of coaching orientation and personal interaction antithetical to a sound sport culture and educational values.

The improvement of the instructional capacity is a result of coaches' individual efforts in matters of acquisition and renewal of knowledge, careful preparation, monitoring and reflection on training and competition processes and outcomes. However, the potential of improvement would be fairly limited if experience were not 
shared, if it did not open to a context of ideas interchange, looking for innovation of coaching practice. Any sport that wants to progress should increment mechanisms of interchange of knowledge and experiences suitable to construction and consolidation of the instructional capacity of coaches and training practices.

Each sport constitutes a community of practice. Its competitive events are an important barometer for coaches, enabling them to make the evolution of their athletes discernible, and allowing the community to infer about the merit and shape of athletes, coaches, programs, and the respective instructional capacity.

Besides, even in youth sport programs oriented to excellence the evaluation criterion should not be uniquely confined to results. It is rather more interesting to put results into perspective and scrutinize the quality of performance in what they could hint the anticipation of future performance.

\section{References}

Cohen DK, Raudenbush SW, Ball DL (2003). Resources, instruction, and research. Educational Evaluation and Policy Analysis, 25 (2), 119-142.

Ericsson KA (2003). Development of Elite Performance and Deliberate Practice: An Update From the Perspective of the Expert Performance Approach In J Starkes \& KA Ericsson (Eds.), Expert Performance in Sports: Advances in Research on Sport Expertise (pp. 49-81). Champaign, IL: Human Kinetics Publishers.

Ericsson KA, Krampe RT, Tesch-Römer C (1993). The role of deliberate practice in the acquisition of expert performance. Psychological Review, 100(3), 363-406.

Kirk D (2004). Framing quality physical education: the elite sport model or Sport Education? Physical Education \& Sport Pedagogy, 9(2), 185-195.

Kirk D, Gorely T (2000). Challenging thinking about the relationship between school physical education and sport performance. European Physical Education Review, 6(2), 119-134.

Kretchmar R (1994). Practical Phylosophy of Sport. Champaign IL, Human Kinetics.

Lee M (1993). Why are you coaching children? In M Lee (Ed.), Coaching children in sports: Principles and practice (pp. 27-38). London: E \& FN Spon.

Queiroz C (1986). Estrutura e organização dos exercícios de treino em futebol. Lisboa: Federação Portuguesa de Futebol. 